\title{
The influences of the number of concrete dowels to shear resistance based on push out tests
}

\author{
Anh-Tuan Vu, Ngoc-Duc Han, Dinh-Hoa Nguyen, Trung-Kien Nguyen \\ Department of Steel and Timber Structures, Faculty of Building and Industrial Construction, Hanoi University of Civil Engineering, \\ 55 Giai Phong road, Hanoi, Vietnam \\ tuanva@nuce.edu.vn, https://orcid.org/0000-0002-0524-7024 \\ duchn@nuce.edu.vn, hoand@nuce.edu.vn \\ kiennt3@nuce.edu.vn, bttps://orcid.org/0000-0003-0966-1617
}

ABSTRACT. To reduce the depth of floor-beam structures and to save the cost of headed-shear studs, many types of shallow composite beam have been developed during the last few years. Among them, the shallow-hollow steel beam consists of web openings, infilled with in-situ concrete (named concrete dowel) has been increasingly focused recently. In this new kind of structure, this concrete dowel plays an important role as the principal shear connector. This article presents an investigation on the shear transferring mechanism and failure behavior of the trapezoid shape concrete dowel. An experimental campaign of static push-out tests has been conducted with variability in the number of web openings (WOs). The results indicate that the mechanical behavior of concrete dowel could be divided into crushing, compression, and tension zones and exhibits brittle behavior. The longitudinal shear resistance and specimen's stiffness are strongly affected by the number of considered WOs.

KEYwords. Concrete Dowel; Shear Connector; Web Opening; Push-out Test; Shallow-Hollow Composite Beam.

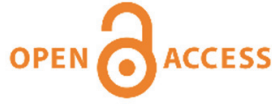

Citation: Vu, A-T., Han, N-D., Nguyen, D$\mathrm{H}$, Nguyen, T-K, The influences of the number of concrete dowels to shear resistance based on push out tests, 59 (2022) 256-264.

Received: 18.08 .2021

Accepted: 04.11.2021

Published: 01.01.2022

Copyright: (C) 2022 This is an open access article under the terms of the CC-BY 4.0, which permits unrestricted use, distribution, and reproduction in any medium, provided the original author and source are credited.

\section{INTRODUCTION}

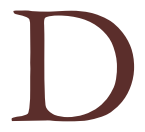
ue to the growing demand for shallow floor beam structures, numerous slim floor system has been developed [1], including Slimfoor [2], Asymmetric Slimflor Beam [3], Ultra Shallow Floor Beam [4-6] and DELTABEAM [7], which are used in commercial and residential buildings, hospitals, schools, etc. The composite action of these structures is the most important factor to consider. Unlike a conventional composite beam system, where the composite action is provided by shear connectors welded to the top flange of the steel beam and embedded in the concrete slab, the composite action of the new type shallow floor is primarily provided by the concrete dowel shear connectors (concrete dowel) between the hollow steel beam and concrete. This latter element ensures the simultaneous working between steel and concrete parts, to be designed as a single unified structure. 
In recent years, the new shallow composite beam has been extensively studying [8-13]. The steel beam consists of web openings, infilled with in-situ concrete (named concrete dowel). In this innovative structure, the concrete dowel plays an important role as the principal shear transfer connector. The behavior of concrete dowel could be estimated based on theoretical calculation method for the shear resistance or experimental investigation method with push-out tests on [14]. The shear behavior of concrete dowel has been addressed in many research works, including empirical/analytical, numerical, and experimental analyses. Huo and D'Mello [8] conducted a series of push-out tests and analytical analysis on the circular-shaped concrete dowels. Hosseinpour et al. [12] investigated the shear resistance of circular, square or rectangular shapes by both experiment and numerical modeling. Limazie and Chen [15] used finite element analysis to investigate the shear resistance and failure behavior of the dowel shapes under direct longitudinal force, as well as the influence and the geometrical requirements of its parameters such as size and spacing of the web opening on the behavior of the shallow cellular composite beam.

So far, to the authors' best knowledge, numerous shapes of web opening in the steel beam have been studied when designing the shallow composite beam. It is however limited to circular, square, or rectangular shapes. In current research, a new trapezoid shape is proposed for the web opening that led to introducing a new type of the shallow-hollow composite beam. As the shear transferring behavior of concrete dowel is the essential element of steel-concrete composite structure, this paper investigates the longitudinal shear resistance and failure behavior of trapezoidal-shape concrete dowels through a series of static push-out tests.

\section{NEW SHALLOW-HOLLOW COMPOSITE BEAM}

$\mathrm{I}$ n a conventional composite beam, a steel-concrete composite beam is formed by a concrete slab attached to the upper flange of $\mathrm{H}$ (or I) steel beam by shear connectors. Normally, the composite action can be archived by means of headedshear studs, welded through the deck to the upper flange. In order to save the cost of studs, avoid welded time on site, and reduce the depth of floor-beam structure, the concrete dowel connector, which uses in-situ concrete filled the opening in web of steel beam was proposed.

Compound steel beam has three parts: bottom, middle plate, and top part. The bottom and top could be welded or folded shape, in order to avoid honeycomb or voids in concrete, the cross-section of top part should be trapezoid, and the bottom could be rectangle. Both sides of the beam have "wing" belong to the middle plate to support the metal decking. With the aim of increasing longitudinal shear resistance, web opening in both sides of the top part is created. This web opening shape could be circle, rectangular or trapezoid. To increase the steel material-saving and reduce manufacturing cost, the trapezoid shape is proposed for the web opening of composite beam. When in-situ concrete at the web openings is hardened, the trapezoid concrete dowels are created and connected on both sides of the steel web. In this research, the rebar was not set through the WO. The 3D configuration of the new shallow-hollow composite beam is illustrated in Fig. 1.

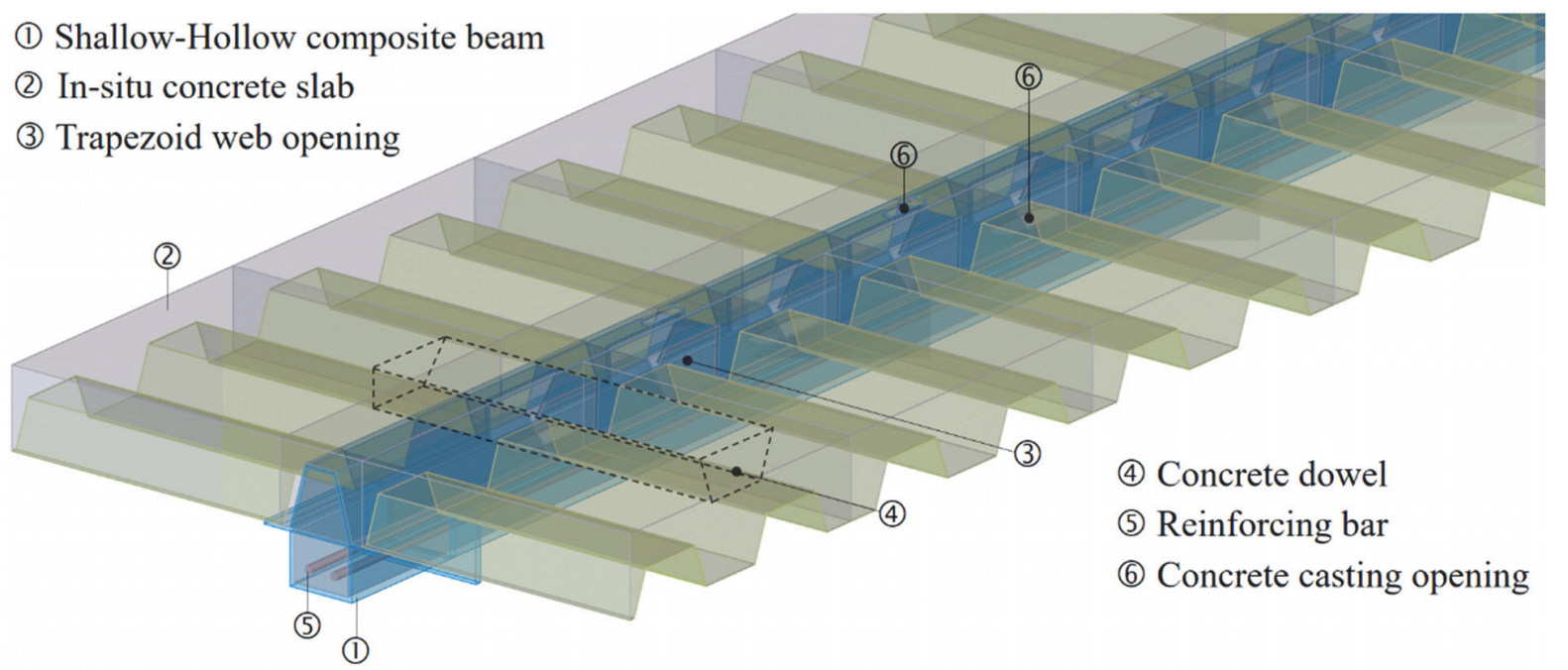

Figure 1: New shallow-hollow composite beam: a 3D illustration. 


\section{EXPERIMENTAL CAMPAIGN: MATERIALS, SPECIMEN, AND PUSH-OUT TESTS}

7 o investigate the influence of concrete dowels on shear strength and failure mechanism, three test groups T1G, T2G, and T3G are classified for the push-out tests in the experimental campaign. The number-letter in the name of the specimen indicates the amount of web opening (WO) in the steel section. Each test group had 3 specimens leading to a total of 9 test specimens. The dimension of single WO and the thickness of the steel section are similar in all the specimens. Normal concrete was used to cast the specimen. To determine the compressive strength of the concrete, cylindrical samples with dimensions of $160 \mathrm{~mm}$ in diameter and $320 \mathrm{~mm}$ in height were prepared and subjected to uniaxial compression test. The compressive strength and tensile strength of the cylinder concrete sample are $33.8 \mathrm{MPa}$ and 2.93 $\mathrm{MPa}$, respectively (which is equivalent to C30/37 to EN1992-1-1 [16]). All test specimens consisted of steel sections and concrete parts as depicted in Figs. 2 and 3. The width of the concrete in specimens is $230 \mathrm{~mm}$, similar for all nine specimens whereas the length of the specimen varied with the number of WO considered. The name and dimensions of specimen configuration are presented in Tab. 1.
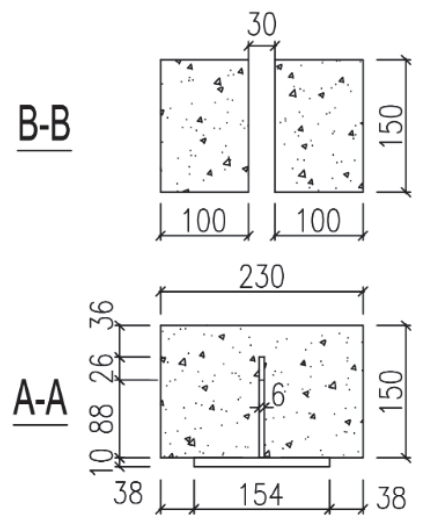

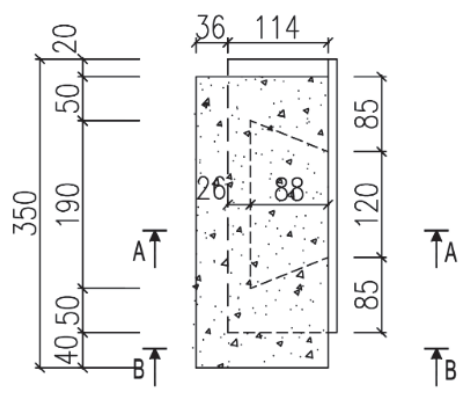

T1G

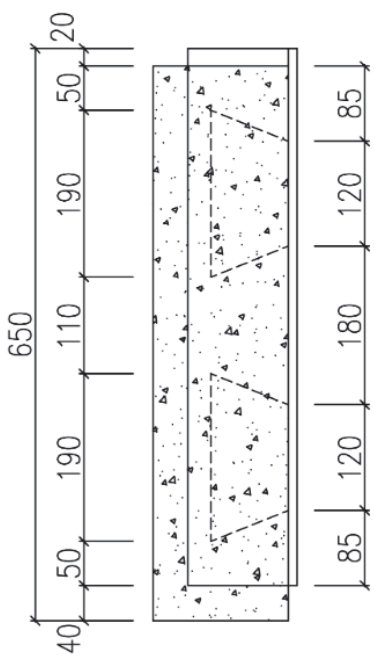

T2G

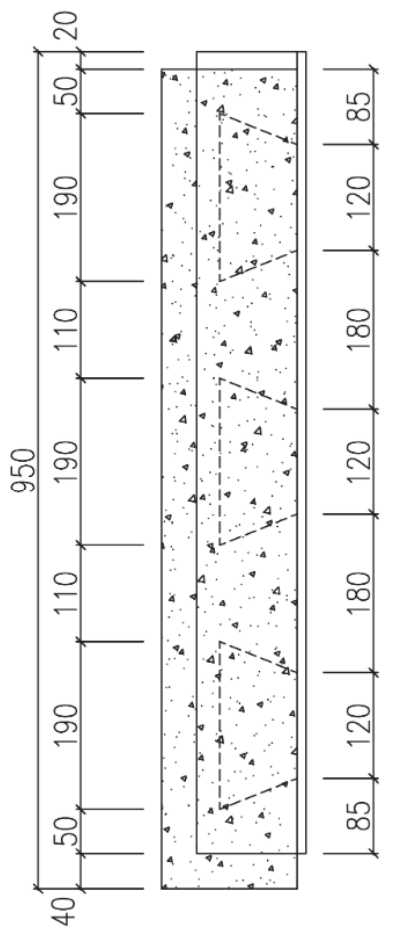

T3G

Figure 2: Specimen configuration (measures are in millimeter).

\begin{tabular}{cccc}
\hline \multirow{2}{*}{ Group of specimens } & \multicolumn{3}{c}{ Dimension of specimens } \\
\cline { 2 - 4 } & $\mathrm{b}$ & $\mathrm{h}$ & Number of WOs \\
T1G & 230 & 350 & 1 \\
T2G & 230 & 650 & 2 \\
T3G & 230 & 950 & 3 \\
\hline
\end{tabular}

Table 1: Specimen configuration.

The tee section used steel grade S235 with yield strength of $235 \mathrm{MPa}$. In all cases, no-debonding grease is applied on to the steel section to avoid friction and shear bond behavior. 

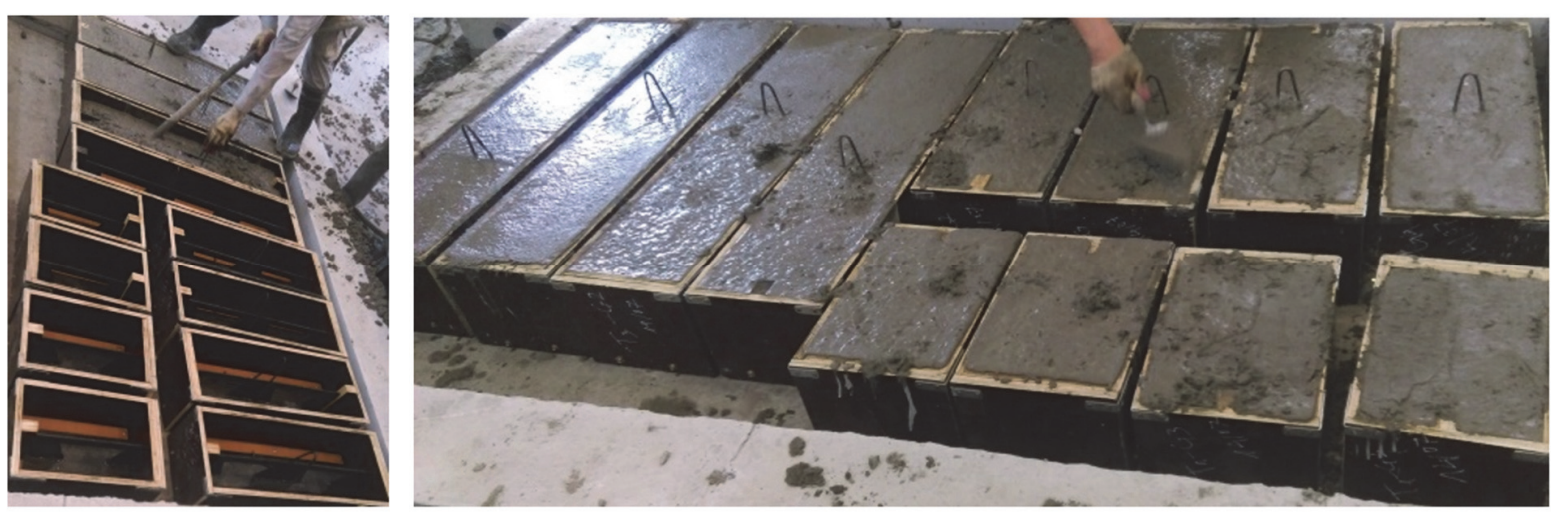

Figure 3: Specimen preparation process: steel section greasing, formwork, and concrete casting.

All specimens were cast and cured in the same conditions at the Laboratory of the Hanoi University of Civil Engineering. The push-out tests were performed according to EN-1994-1-1 [14]. Hydraulic jack with capacity of $1000 \mathrm{kN}$ and load-cell was used to control the loading. The load-slip relationship is automatically recorded via TDS530 data logger. The load is applied to the specimen by $25 \mathrm{~mm}$ thickness end steel-plate which was welded on the top of the steel tee section. LVDTs (Linear Variable Differential Transformer) are positioned as depicted in Figs. 4 and 5 to measure the slips at the surface between the steel section and concrete part, as well as to control the test's centricity.

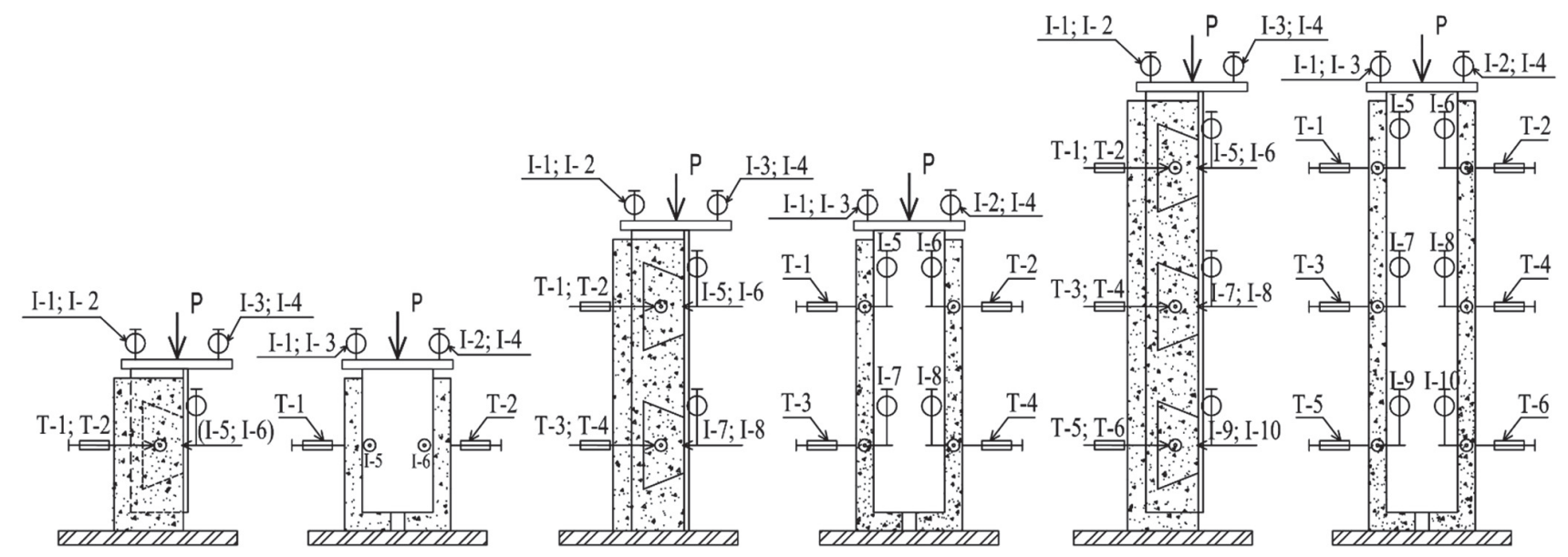

Figure 4: Push-out test designation and LVDTs location. I- and T- refer to the digital gauge that measure vertical and horizontal displacement.
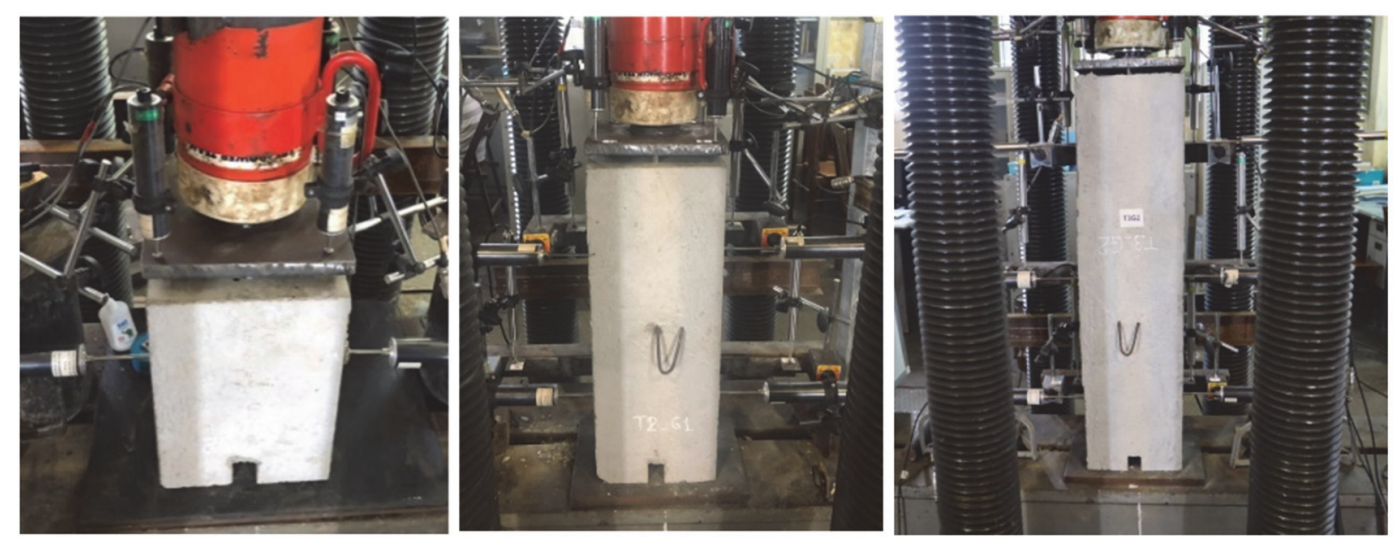

Figure 5: Push-out test set-up specimens of groups T1G, T2G and T3G (from left to right). 


\section{RESULTS AND DISCUSSION}

\section{Load-slip relationship and failure mechanism}

7 he applied load was measured by load cell and relative slips of steel and concrete were determined through LVDTs. The axial load versus slip curves obtained from experiments are displayed in Fig. 6(a-c). The load-slip behavior clearly showed that the shear resistance is affected the number of WOs considered, i.e., concrete dowels in pushout tests. As increasing the number of WOs, the ultimate load and relative stiffness of the specimen increase as well. According to EN1994-1-1 [14], all the archived slip values are smaller than 6mm, so the load-ship relationships indicate that the concrete dowel connector exhibits brittle failure. The brittle behavior of concrete dowel came from the inherent material characteristic of concrete. The relative vertical displacement between the steel section and concrete part (slip) is relatively small. The slip value, corresponding to the ultimate loads, ranges from $0.2 \mathrm{~mm}$ to $0.7 \mathrm{~mm}$, inversely proportional to the number of WOs.
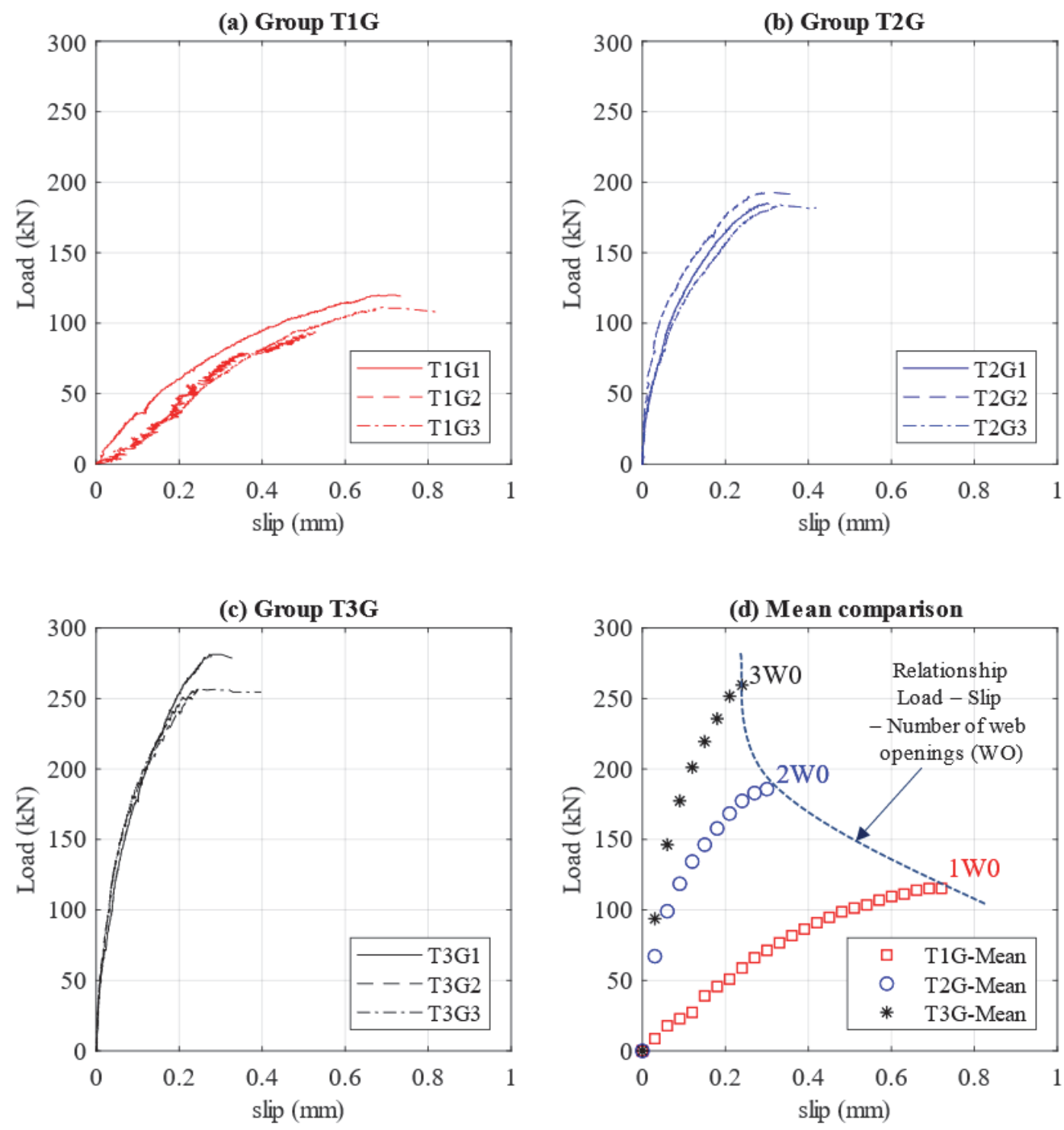

Figure 6: Load-slip relationship for specimen group T1G, T2G, T3G.

The failure shapes of test groups T1G, T2G, and T3G are presented in Fig. 7. This figure shows that the failure mechanism of concrete dowel of all test groups is quite similar. The top part of concrete dowel is in compression zone. Especially, at 
the acute angle of the trapezoid opening section, the concrete was crushed due to the longitudinal shear force. The crushing section is almost smooth. Furthermore, Fig. 7 indicates that the lower part of the concrete in the trapezoid section is convex (in the transverse direction of the web of the steel section), suggesting that the tensile splitting failure occurred at the lower part of the concrete dowel. It can be seen that the shear connector's bearing capacity is composed primarily of the compressive resistance of the concrete part of the dowel (which is in contact with the upper trapezoid's edge) and the tensile splitting resistance of the lower concrete part in the transverse direction. Those observations are in agreement with the failure profile shown experimentally and numerically by $[8,13]$.

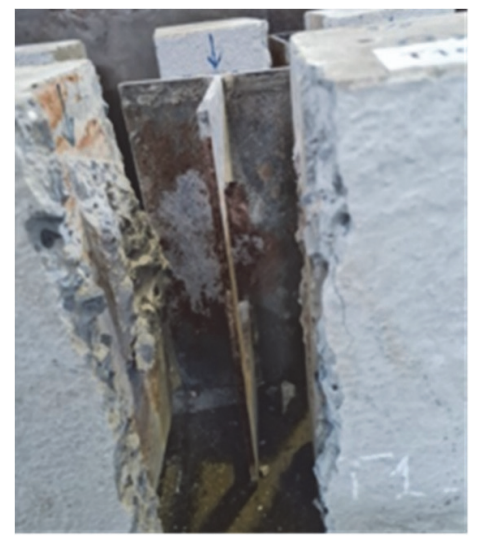

(a) $\mathrm{T} 1 \mathrm{G}$

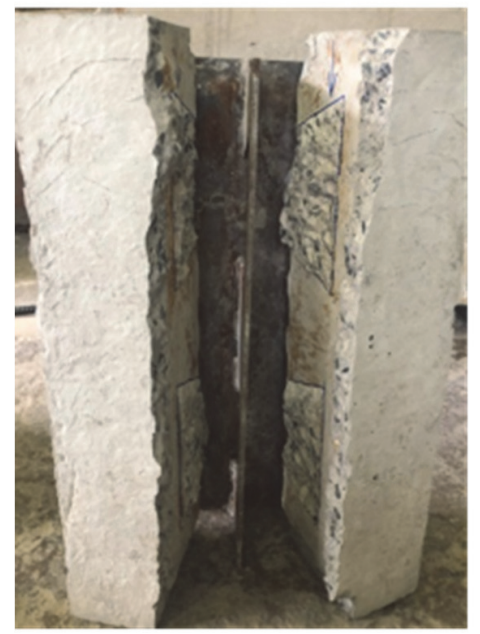

(b) $\mathrm{T} 2 \mathrm{G}$

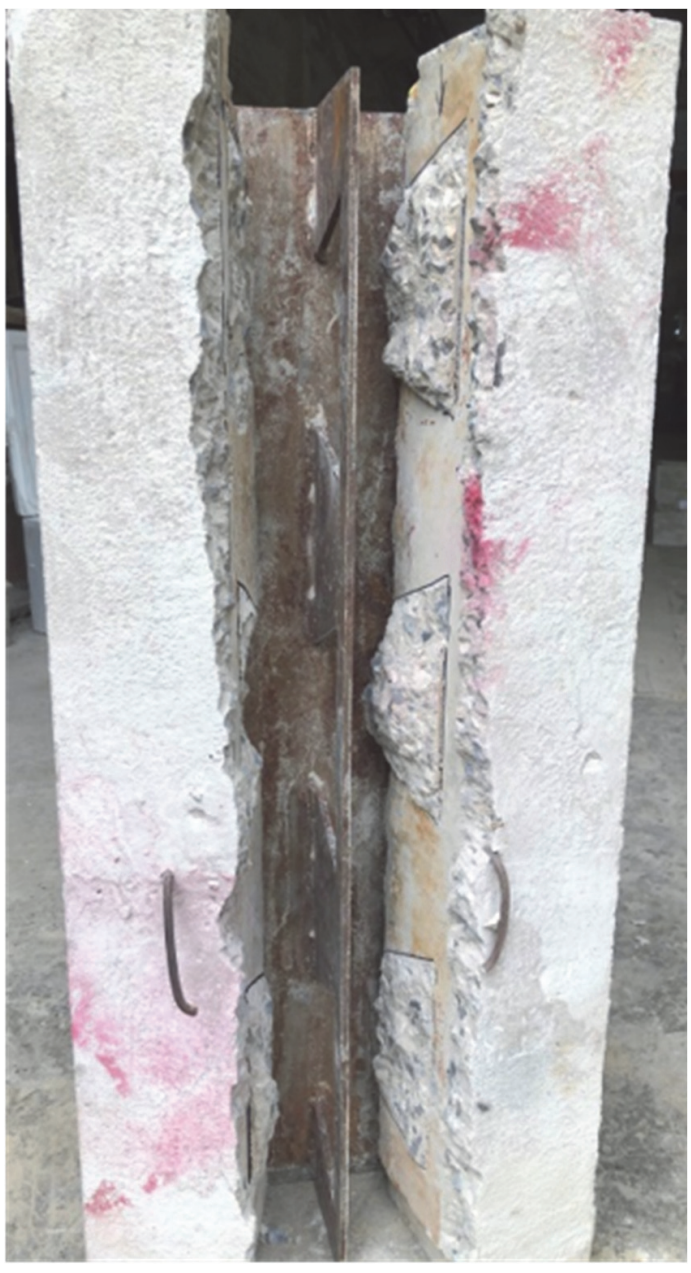

(c) T3G

Figure 7: Failure of specimens.

Based on experimental observations through a total of nine static push-out tests, a schematic illustration of the failure mode of a single trapezoid shape concrete dowel is given in Fig. 8. The failure mechanism suggests that the compression zone is not homogeneous on the upper edge of the trapezoid opening, i.e., section 2-2 is different from section 3-3. A small zone, where the concrete is totally crushed, is observed. At the lower part of the section, the concrete is initially found in triaxial stress state. As the shear force increases, the shear-induced failure of the specimen is triggered by the splitting of the concrete, characterized by tension zone as described in the figure.

\section{Ultimate loads}

The values of ultimate loads of all specimens and the mean values for each test group are presented in Tab. 2 .

The average ultimate loads for T1G, T2G, and T3G test group are $109.9 \mathrm{kN}, 189.9 \mathrm{kN}$, and $264.8 \mathrm{kN}$, respectively. It is shown that the ultimate loads increase with the number of concrete dowels. The percentage of the difference between T3G, 
T2G, and T1G (reference group test) are $72.8 \%$ and $140.9 \%$. The finding suggests that exists simultaneous behavior of dowels in the specimen.

In order to evaluate the load-slip relationships for all test groups, the mean load-slip relationship has been determined for each group test and displayed in Fig. 6(d). The mean curve reveals that the slip stiffness (which is defined as the ratio of the ultimate load and the corresponding slip), the ultimate load is both increased with the number of dowels considered. Besides, the higher number of WO used, the smaller relative slip is observed. When considering the relationship between the slip and the number of WO, it seems to exist a plateau as marked in Fig. 6(d).
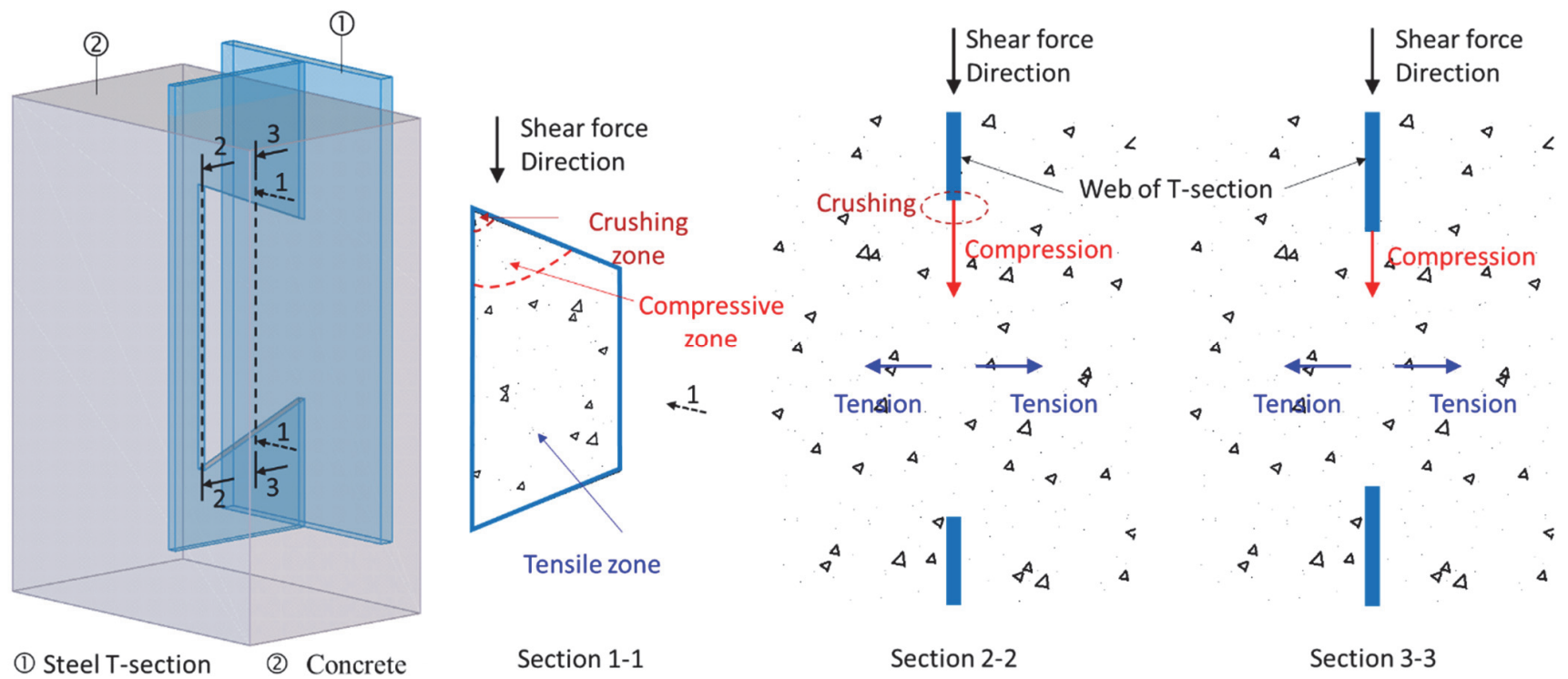

Figure 8: Schematic illustration of failure mechanism of a single trapezoid shape concrete dowel.

\begin{tabular}{cccccc}
\hline Group & $\begin{array}{c}\text { Specimen 1 } \\
(\mathrm{kN})\end{array}$ & $\begin{array}{c}\text { Specimen 2 } \\
(\mathrm{kN})\end{array}$ & $\begin{array}{c}\text { Specimen 3 } \\
(\mathrm{kN})\end{array}$ & Mean & $\begin{array}{c}\text { Difference } \\
\text { from T1G }(\%)\end{array}$ \\
T1G & 124.6 & 93.9 & 111.2 & 109.9 & - \\
T2G & 185.2 & 193.2 & 191.3 & 189.9 & 72.8 \\
T3G & 281.2 & 256.5 & 256.6 & 264.8 & 140.9 \\
\hline
\end{tabular}

Table 2: Push-out test results: ultimate loads.

\section{Simultaneous behavior of concrete dowels}

The values obtained by dividing the ultimate load of the specimens by the number of the dowels are considered as the shear capacity of the single dowel. The average shear capacity values for all test groups are summarized in Tab. 3 .

The tested results in Tab. 3 indicate that when increasing the number of dowels, the ultimate load increased due to the simultaneous behavior of concrete dowels. On the contrary, the average shear strength decreased. It means that the simultaneous behavior between the shear connectors is not accumulated. In the other words, the ultimate load is not simply equal to the product of the shear capacity of a single dowel multiplied by the number of dowels in specimens. In such case, the influence of the number of concrete dowels must be taken into account. The coefficient of simultaneous working between dowels in the sample is defined as the ratio of the shear capacity of T2G, T3G groups, and T1G group. The value of this coefficient indicates that as the number of WO increases, the coefficient of simultaneous behavior decreases. This latter confirms again that the influence of the number of concrete dowels on the shear resistance behavior is not negligible. 
Besides the shear capacity values, the slip stiffness of the dowel is considered. As presented in Tab. 4, it is found that the slip stiffness was influenced by the number of dowels in specimens, the average slip stiffness for groups T2G and T3G is greater than that of group T1G about $92 \%$ and $148 \%$, respectively.

\begin{tabular}{ccccc}
\hline Group & $\begin{array}{c}\text { Ultimate load } \\
(\mathrm{kN})\end{array}$ & $\begin{array}{c}\text { Number of } \\
\text { dowels }\end{array}$ & $\begin{array}{c}\text { Average Shear } \\
\text { strength }\end{array}$ & Coefficient \\
T1G & 109.9 & 1 & 109.9 & 1.0 \\
T2G & 189.9 & 2 & 94.9 & 0.9 \\
T3G & 264.8 & 3 & 88.3 & 0.8 \\
\hline
\end{tabular}

Table 3: Influence of the number of dowels in the simultaneous working of dowels.

\begin{tabular}{ccccc}
\hline Group & $\begin{array}{c}\text { Mean slip } \\
(\mathrm{mm})\end{array}$ & $\begin{array}{c}\text { Shear } \\
\text { strength } \\
(\mathrm{kN})\end{array}$ & $\begin{array}{c}\text { Slip stiffness } \\
(\mathrm{kN} / \mathrm{mm})\end{array}$ & $\begin{array}{c}\text { Difference } \\
\text { from T1G } \\
(\%)\end{array}$ \\
T1G & 0.71 & 109.9 & 154.8 & - \\
T2G & 0.32 & 94.9 & 296.6 & 92 \\
T3G & 0.23 & 88.3 & 383.9 & 148 \\
\hline
\end{tabular}

Table 4: Properties of concrete dowels (average value).

\section{CONCLUSION}

A n experimental campaign has been conducted and presented in this paper to investigate the failure behavior of concrete dowel subjected to push-out test. Nine specimens divided into three groups were considered. Similar conditions are employed in all groups except the number of WO. Thanks to the observation, the following conclusion could be drawn:

- The shear failure of all specimens is likely to suffer brittle failure due to the brittle behavior of the concrete.

- Post-failure analysis was performed indicating that the failure mechanism of the dowel involves crushing in a small compression zone and tensile splitting of concrete in the rest area of WO.

- Compared to T1G group, we found that the ultimate load of T2G and T3G group was increased by $72.8 \%$ and $140.9 \%$ when the number of dowels increased twice and three times.

- By evaluating the simultaneity of dowel behavior, it is found that the simultaneous behavior between the shear connectors is not accumulated. The influence of the number of dowels is not negligible. The coefficient of the simultaneous working of the dowels decreases with the increase of the dowel number.

- Finally, the slip stiffness of the shear connector was influenced by the number of dowels in specimens. The slip stiffness is increased with increasing the number of dowels.

It should be noted that the present research is purely experimental. Mechanical analyses were done based on the concrete behavior and compared to other push-out tests' results in the literature. In the future work, more experiments supported by numerical modeling (finite or combined finite-discrete types) element modeling by systematically varying the geometrical dimensions and concrete grade will be performed. These will be served as ingredients for deriving an empirical equation in predicting the shear resistance of concrete dowel.

\section{ACKNOWLEDGMENT}

he authors acknowledge the support from Vietnam Ministry of Construction through research project no. TC1221. 


\section{REFERENCES}

[1] Ahmed, I.M., Tsavdaridis, K.D. (2019). The evolution of composite flooring systems: applications, testing, modelling and eurocode design approaches, J. Constr. Steel Res., 155, pp. 286-300, DOI: 10.1016/j.jcsr.2019.01.007.

[2] ArcelorMittal. (2017). Slim-Floor An innovative concept for floors.

[3] Rackham, J.W., Hicks, S.J., Newman, G.M. (2006). Design of asymmetric slimflor beams with precast concrete slabs, Citeseer.

[4] Tsavdaridis, K.D., D Mello, C., Hawes, M. (2009). Experimental study of ultra shallow floor beams (USFB) with perforated steel sections. Nordic Steel 09, pp. 312-319.

[5] Lawson, M. (2011). Enhanced design of ultra shallow floor beams, Echnical Pap. New Steel Constr. Mag.

[6] Tsavdaridis, K.D., D’Mello, C., Huo, B.Y. (2013). Experimental and computational study of the vertical shear behaviour of partially encased perforated steel beams, Eng. Struct., 56, pp. 805-22, DOI: 10.1016/j.engstruct.2013.04.025.

[7] PeikkoGroup. (2021). Technical Manual Deltabeam Composite Beams Slim Floor Structure with integrated fireproofing DELTABEAM Composite Beams, .

[8] Huo, B.Y., D’Mello, C.A. (2013). Push-out tests and analytical study of shear transfer mechanisms in composite shallow cellular floor beams, J. Constr. Steel Res., 88, pp. 191-205, DOI: 10.1016/j.jcsr.2013.05.007.

[9] Huo, B.Y., D’Mello, C.A. (2017).Shear transferring mechanisms in a composite shallow cellular floor beam with web openings. Structures, 9, pp. 134-46.

[10] Limazie, T., Chen, S. (2017). Effective shear connection for shallow cellular composite floor beams, J. Constr. Steel Res., 128, pp. 772-788, DOI: 10.1016/j.jcsr.2016.10.010.

[11] Duc, H.N., Tuan, V.A., Dat, N.T. (2018). Behaviour and push-out test of concrete dowel connectors for longitudinal shear in shallow-hollow composite beams, J. Sci. Technol. Civ. Eng. (STCE)-NUCE, 12(5), pp. 1-9, DOI: 10.31814/stce.nuce2018-12(5)-01.

[12] Hosseinpour, E., Baharom, S., Badaruzzaman, W.H.W., Shariati, M., Jalali, A. (2018). Direct shear behavior of concrete filled hollow steel tube shear connector for slim-floor steel beams, Steel Compos. Struct., 26(4), pp. 485-499, DOI: $10.12989 /$ scs.2018.26.4.485.

[13] Hosseinpour, E., Baharom, S., Badaruzzaman, W.H.W., Al Zand, A.W. (2018). Push-out test on the web opening shear connector for a slim-floor steel beam: Experimental and analytical study, Eng. Struct., 163, pp. 137-152, DOI: 10.1016/j.engstruct.2018.02.047.

[14] EN 1994-1-1. (2004). Eurocode 4: Design of steel and concrete composite structures, part 1.1: General rules and rules for building, .

[15] Limazie, T., Chen, S. (2016). FE modeling and numerical investigation of shallow cellular composite floor beams, J. Constr. Steel Res., 119, pp. 190-201, DOI: 10.1016/j.jcsr.2015.12.022.

[16] EN 1992-1-1. (2004). Eurocode 2: Design of concrete structures, part 1.1: General rules and rules for building, BS En 1992. 